\title{
Optimization of Chitin Extraction from Agaricus bisporus Using a Taguchi Design ${ }^{+}$
}

\author{
Mălina Deșliu-Avram, Cătălina-Diana Cristea, Diana Constantinescu-Aruxandei * \\ and Florin Oancea * \\ National Institute for Research \& Development in Chemistry and Petrochemistry-ICECHIM, Spl. \\ Independentei nr. 202, 060201 Bucharest, Romania; desliu.avram.malina@gmail.com (M.D.-A.); \\ cristeacatalina95@gmail.com (C.-D. C.) \\ * Correspondence: diana.constantinescu@icechim-rezultate.ro (D.C.-A.); Florin.Oancea@icechim.ro (F.O.) \\ + Presented at the 15th International Symposium "Priorities of Chemistry for a Sustainable Development" \\ PRIOCHEM, Bucharest, Romania, 30th October-1st November 2019.
}

Published: 14 October 2019

Keywords: chitin extraction; Agaricus bisporus; optimization; Taguchi Design

Edible mushrooms, e.g., Agaricus bisporus (A. bisporus), represents a well-known source of nutrients for humans because of their low calorie content and high content of proteins, carbohydrates, polyunsaturated fatty acids, phenolic compounds, dietary fibers, vitamins ( $B_{1}-B_{3}, B_{5}, B_{6}, B_{9}, B_{12}, C_{\text {, }}$ $\left.\mathrm{D}_{2}\right)$, minerals $(\mathrm{Fe}, \mathrm{Mg}, \mathrm{P}, \mathrm{K}, \mathrm{Na}, \mathrm{Zn})$, lectins, and other bioactive compounds. Their antioxidant, antimicrobial, dietary, and anti-allergenic content means they can be used for novel applications such as additives for food, nutraceuticals, or cleaning products [1]. The objective of this paper was to establish the optimal process parameters for chitin extraction from A. bisporus using an experimental Taguchi orthogonal array (OA) factorial designs under response surface methodology (RSM). A linear model with four independent variables $(\mathrm{A}=$ liquid/solid ratio, $\mathrm{mL} / \mathrm{g} ; \mathrm{B}=$ extraction temperature, ${ }^{\circ} \mathrm{C} ; \mathrm{C}=$ extraction time, $\mathrm{h} ; \mathrm{D}=$ stirring speed, $\mathrm{rpm}$ ) and three levels was used to maximize the relative extraction efficiency. The mushrooms were grinded and lyophilized. Conventional deproteinization and demineralization treatment with $\mathrm{NaOH}$ solution was used. Different volumes of $\mathrm{NaOH}$ solution were mixed with lyophilized A. bisporus in a round-bottomed flask with a reflux cooler for different extraction temperatures, times, and stirring speeds on a hot plate with magnetic stirrer. The extracted chitin was between $7.2 \%$ and $16 \%$, where the minimum content obtained was for $\mathrm{A}=100 \mathrm{~mL} / \mathrm{g}, \mathrm{B}=100^{\circ} \mathrm{C}, \mathrm{C}=4 \mathrm{~h}$, and $\mathrm{D}=900 \mathrm{rpm}$, and the maximum for $\mathrm{A}=80 \mathrm{~mL} / \mathrm{g}, \mathrm{B}=80^{\circ} \mathrm{C}, \mathrm{C}=4 \mathrm{~h}$, and $\mathrm{D}=600 \mathrm{rpm}$. The polynomial equation coefficients were established using the Design-Expert ${ }^{\circledR}$ Software Version 11 (Stat-Ease, Inc. Minneapolis, MN, USA). The optimum chitin content was at $\mathrm{A}=116.782 \mathrm{~mL} / \mathrm{g} ; \mathrm{B}=80.759^{\circ} \mathrm{C} ; \mathrm{C}=4.109 \mathrm{~h}$, and $\mathrm{D}=973.715 \mathrm{rpm}$, which is in accordance with the predicted values obtained using RSM. A positive influence on the chitin content was observed for the liquid/solid ratio (A), the extraction temperature (B), and the extraction time (C). The relevance of the regression analysis was determined using analysis of variance (ANOVA). This work could be a starting point in designing and optimizing new processes for higher valorization of chitin extraction.

Acknowledgments: This work was funded by Project PN.19.23.01.01 Smart-Bi, financially supported by UEFISCDI, Ministry of Research and Innovation. We also thank the Government of Romania, Ministry of Research and Innovation, Project PFE 31/2018, Enhancing the INCDCP-ICECHIM research and innovation potential within the field of inter-disciplinary and cross-sectoral key enabling technologies - TRANS-CHEM. Project.

Conflicts: Authors declare no conflict of interest. 


\section{References}

1. Ramos, M.; Burgos, N.; Barnard, A.; Evans, G.; Preece, J.; Graz, M.; Ruthes, A.C.; Jiménez-Quero, A.; Martínez-Abad, A.; Vilaplana, F.; et al. Agaricus bisporus and its by-products as a source of valuable extracts and bioactive compounds. Food Chem. 2019, 292, 176-187.

(C) 2019 by the authors. Licensee MDPI, Basel, Switzerland. This article is an open access article distributed under the terms and conditions of the Creative Commons Attribution (CC BY) license (http://creativecommons.org/licenses/by/4.0/). 